Int. J. Environ. Sci. Tech.

(C) Spring 2006, Vol. 3, No. 2, pp. 173-176

\title{
Effect of aluminum and chromium on the growth and germination of mesquite (Prosopis juliflora swartz.) DC.
}

\author{
${ }^{1}$ Sh. N. Jamal, ${ }^{1}$ M. Z. Iqbal and ${ }^{2 *}$ M. Athar \\ ${ }^{1}$ Department of Botany, University of Karachi, Karachi, Pakistan \\ ${ }^{2}$ California Department of Food and Agriculture, Sacramento, USA
}

Received 10 August 2005;

revised 15 December 2005;

accepted 27 February 2006;

available online 20 April 2006

\begin{abstract}
Prosopis seeds were grown under controlled environment in solution of aluminum and chromium at different concentration alone as well as combined together. The effect of these metals was studied on seed germination, root length, shoot length, seedling length and dry biomass. Aluminum and chromium alone, and combined together showed no effects on germination and dry biomass. Chromium alone was found toxic to root, shoot and seedling length. However, application of different concentrations of aluminum increased the root, shoot and seedling growth. It may be concluded that aluminum is not as toxic as chromium, and their combined treatment showed the intermediate effect by ameliorating the impact of one another.
\end{abstract}

Key words: Aluminum, chromium, germination, growth, toxicity, Prosopis juliflora

*Corresponding Author, E-mail: atariq@cdfa.ca.gov

\section{INTRODUCTION}

Heavy metals are one of the main sources of environmental pollution, which becomes the greatest risk to the plants life. Heavy metals like aluminum and chromium which are used in tanning and pigment industry and disposed from the industry effluents. Increased aluminum and chromium metal solubility in soil water due to acid precipitation has aroused considerable interest in the problem of their toxicity in plants. These metals reduce the growth of plant, decreased net photosynthesis and the biomass of plants. Heavy metals persist indefinitely in soil thereby posing an ever-increasing threat to human health and agriculture (Leyval et al. 1995). Metal toxicity primarily depends on plant species as they exhibit considerable genetic variation in their ability in tolerating amounts and the concentration of specific heavy metals (Vojtechova and Leblova 1991). Some heavy metals are essential micronutrients for plants but their excess may result in metabolic disorders and growth inhibition in most of the plant species (Claire et al, 1991). The apparent damage of plant tissues due to excessive amount of heavy metals in the growth medium can be used as an indicative of toxic effects of metals (Mullar et al. 2000). Prosopis juliflora is better known as mesquite tree and a legume plant. Many species of
Prosopis are aggressive and pioneer and because of this the genus is considered a weed in many parts of its natural distribution and even in some countries where it is exotic. It is a multipurpose tree/shrub that is used to feed livestock, shade and windbreak, charcoal, lives fence and firewood as well as house construction (Hailu, 2002; Mohamed, 1997). However, it is jeopardizing the daily activities of the nomadic pastoralist and agriculturalists, on the other hand. It invades the farmlands, rangelands, irrigation canals, narrowing roads (Hailu, 2002; Kassahun, 1999). Some groups of people are needy for the survival of the species whereas other, are desperately looking for systems to eradicate the species from the area. The present study was carried out to see the effect of aluminum and chromium alone and combined together on germination and seedling growth of mesquite as these are the key events for the establishment of plants under any prevailing environment (Welbaum et al. 1998).

\section{MATERIALS AND METHODS}

Seeds of Prosopis juliflora (Swartz.) DC. were collected from the plants growing at Karachi University campus. Seeds were surface sterilized with dilute solution of sodium-hypo-chloride (1.2 \%) for 4-6 
minutes followed by successive changes of sterilized distilled water. Aluminum was applied in the form of aluminum nitrate $\left[\left(\mathrm{Al}\left(\mathrm{NO}_{3}\right)_{3}\right]\right.$ whereas chromium was applied in the form of potassium dichromate $\left(\mathrm{K}_{2} \mathrm{Cr}_{2} \mathrm{O}_{7}\right.$.) The concentrations used were 20, 40, 60, 80 and 100 ppm of aluminum and chromium prepared in distilled water. Control was free from any heavy metal. Ten seeds were placed in each petri dish for germination. Seeds were germinated under dark conditions with 3 $\mathrm{mL}$ aluminum and chromium solution applied singly and in combined form. The seeds were considered germinated with the emergence of radicles. The germinated seeds were then moved to the laboratory under 160-watt light with 10/14 h day and night period respectively. The temperature regime was kept at $31 \pm 2$ ${ }^{\circ} \mathrm{C}$ and the average relative humidity at $75 \%$, which was recorded by Sling psychrometer in the laboratory. After 10 days, root, shoot and seedling length of three of the tallest seedlings were measured. The seedlings were dried in an oven at $80^{\circ} \mathrm{C}$ for $24 \mathrm{~h}$ and weighed. Data were analyzed statistically and mean were compared with LSD multiple mean comparison test at $\mathrm{P}<0.05$.

\section{RESULTS}

Seeds of $P$. juliflora germinated under all the treatments. The germination of seeds was $97 \%$ at different concentration of both heavy metals whereas in control it was 98\% (Tables 1, 2 and 3). All the seeds showed enhanced germination and germinated within two days. The effect of treatments at different concentration (20,40, 60, 80, 100 ppm) was slightly different. Aluminum treatment alone enhanced the root length while chromium alone and combined with aluminum showed the inhibitory effect. The length of root in chromium and combined treatment decreased as concentrations were increased but the effect was not significant. Chromium alone showed high magnitude of inhibition (P,).05) than combined and aluminum treatments (Table 1, 2 and 3). Aluminum treatment showed slight enhancement in shoot length than root. The activity of aluminum treatment was again found enhancing on seedling length whereas chromium treatment showed much reduction in the growth. Among different concentrations, the length was decreased as the concentration was increased. Both chromium alone and in combination showed the inhibitory effect while aluminum showed enhancing effect on seedling length. The dry biomass was not affected by any treatment except that there was a little inhibitory effect with chromium treatment. Aluminum alone and in combination showed better effect than chromium.

Table 1: Effect of aluminum on germination and growth of Prosopis juliflora

\begin{tabular}{cclcccc}
\hline Treatments & $\begin{array}{c}\text { Conc. } \\
(\mathrm{ppm})\end{array}$ & Germination $(\%)$ & $\begin{array}{c}\text { Root length } \\
(\mathrm{cm})\end{array}$ & $\begin{array}{c}\text { Shoot length } \\
(\mathrm{cm})\end{array}$ & $\begin{array}{c}\text { Seedling length } \\
(\mathrm{cm})\end{array}$ & $\begin{array}{c}\text { Dry biomass } \\
(\mathrm{mg})\end{array}$ \\
\hline Control & 00 & $97.7 \pm 3.9 \mathrm{a}$ & $6.36 \pm .56 \mathrm{a}$ & $6.69 \pm 0.14 \mathrm{ab}$ & $13.06 \pm 0.56 \mathrm{a}$ & $18.0 \pm 0.3 \mathrm{a}$ \\
& 20 & $97.7 \pm 3.9 \mathrm{a}$ & $8.94 \pm 0.41 \mathrm{~b}$ & $7.13 \pm 0.80 \mathrm{~b}$ & $16.07 \pm 1.21 \mathrm{~b}$ & $18.2 \pm 0.6 \mathrm{a}$ \\
& 40 & $95.5 \pm 3.9 \mathrm{a}$ & $9.36 \pm 1.31 \mathrm{~b}$ & $5.58 \pm 1.29 \mathrm{a}$ & $14.94 \pm 1.55 \mathrm{ab}$ & $18.1 \pm 0.8 \mathrm{a}$ \\
$\mathrm{Al}$ & 60 & $100.0 \pm 0.0 \mathrm{a}$ & $7.84 \pm 1.47 \mathrm{ab}$ & $7.07 \pm 0.58 \mathrm{~b}$ & $14.91 \pm 1.96 \mathrm{ab}$ & $18.6 \pm 0.0 \mathrm{a}$ \\
& 80 & $100 \pm 0.0 \mathrm{a}$ & $5.98 \pm 2.29 \mathrm{a}$ & $6.51 \pm 0.35 \mathrm{ab}$ & $12.5 \pm 1.95 \mathrm{a}$ & $17.7 \pm 0.7 \mathrm{a}$ \\
& 100 & $97.7 \pm 3.9 \mathrm{a}$ & $7.8 \pm 0.23 \mathrm{ab}$ & $6.82 \pm 0.13 \mathrm{ab}$ & $14.62 \pm 0.23 \mathrm{ab}$ & $17.2 \pm 0.1 \mathrm{a}$ \\
\hline
\end{tabular}

Numbers followed by the same letters in the same column are not significantly different at $\mathrm{P}<0.05$.

\pm Standard Error of the means.

Table 2: Effect of chromium on germination and growth of Prosopis juliflora

\begin{tabular}{cclcccc}
\hline Treatment & $\begin{array}{c}\text { Conc. } \\
(\mathrm{ppm})\end{array}$ & Germination $(\%)$ & $\begin{array}{c}\text { Root length } \\
(\mathrm{cm})\end{array}$ & $\begin{array}{c}\text { Shoot length } \\
(\mathrm{cm})\end{array}$ & $\begin{array}{c}\text { Seedling length } \\
(\mathrm{cm})\end{array}$ & $\begin{array}{c}\text { Dry biomass } \\
(\mathrm{mg})\end{array}$ \\
\hline Control & 00 & $97.7 \pm 3.9 \mathrm{a}$ & $6.36 \pm .56 \mathrm{~b}$ & $6.69 \pm 0.14 \mathrm{a}$ & $13.06 \pm 0.56 \mathrm{~b}$ & $18.0 \pm 0.3 \mathrm{a}$ \\
& 20 & $100.0 \pm 0.0 \mathrm{a}$ & $4.51 \pm 0.54 \mathrm{a}$ & $6.05 \pm 0.40 \mathrm{a}$ & $10.56 \pm 0.25 \mathrm{ab}$ & $17.5 \pm .0 .6 \mathrm{a}$ \\
& 40 & $100.0 \pm 0.0 \mathrm{a}$ & $3.92 \pm 0.23 \mathrm{a}$ & $6.53 \pm 0.34 \mathrm{a}$ & $9.71 \pm 1.79 \mathrm{ab}$ & $17.5 \pm 0.6 \mathrm{a}$ \\
$\mathrm{Cr}$ & 60 & $97.7 \pm 3.9 \mathrm{a}$ & $3.57 \pm 1.80 \mathrm{a}$ & $6.30 \pm 0.59 \mathrm{a}$ & $8.88 \pm 3.82 \mathrm{a}$ & $17.8 \pm 0.7 \mathrm{a}$ \\
& 80 & $95.3 \pm 3.9 \mathrm{a}$ & $2.57 \pm 0.20 \mathrm{a}$ & $6.35 \pm 0.58 \mathrm{a}$ & $8.93 \pm 0.70 \mathrm{a}$ & $17.0 \pm 0.5 \mathrm{a}$ \\
& 100 & $95.3 \pm 7.7 \mathrm{a}$ & $2.96 \pm 1.41 \mathrm{a}$ & $6.41 \pm 0.41 \mathrm{a}$ & $9.37 \pm 1.80 \mathrm{a}$ & $17.2 \pm 0.4 \mathrm{a}$ \\
\hline
\end{tabular}

Figures followed by the same letters in the same column are not significantly different at $\mathrm{P}<0.05$.

\pm Standard Error of the means. 
Effect of aluminum...

Table 3: Effect of combined treatment of aluminum and chromium on germination and growth of Prosopis juliflora

\begin{tabular}{ccccccc}
\hline Treatments & $\begin{array}{c}\text { Conc. } \\
(\mathrm{ppm})\end{array}$ & Germination $(\%)$ & $\begin{array}{c}\text { Root length } \\
(\mathrm{cm})\end{array}$ & $\begin{array}{c}\text { Shoot length } \\
(\mathrm{cm})\end{array}$ & $\begin{array}{c}\text { Seedling length } \\
(\mathrm{cm})\end{array}$ & $\begin{array}{c}\text { Dry Biomass } \\
(\mathrm{mg})\end{array}$ \\
\hline Control & 00 & $97.7 \pm 3.9 \mathrm{a}$ & $6.36 \pm 0.56 \mathrm{a}$ & $6.69 \pm 0.14 \mathrm{a}$ & $13.06 \pm 0.56 \mathrm{~b}$ & $18.0 \pm 0.3 \mathrm{~b}$ \\
& 20 & $95.5 \pm 3.9 \mathrm{a}$ & $5.01 \pm 1.05 \mathrm{a}$ & $6.08 \pm 1.68 \mathrm{a}$ & $11.1 \pm 1.09 \mathrm{ab}$ & $16.0 \pm 2.3 \mathrm{ab}$ \\
& 40 & $93.3 \pm 6.7 \mathrm{a}$ & $4.53 \pm 0.42 \mathrm{a}$ & $5.35 \pm 1.46 \mathrm{a}$ & $9.77 \pm 1.31 \mathrm{a}$ & $14.6 \pm 0.4 \mathrm{a}$ \\
Equally & 60 & $95.5 \pm 7.7 \mathrm{a}$ & $4.58 \pm 0.25 \mathrm{a}$ & $6.42 \pm 0.27 \mathrm{a}$ & $11.0 \pm 0.43 \mathrm{ab}$ & $18.4 \pm 0.2 \mathrm{~b}$ \\
Combined $(\mathrm{Al}+\mathrm{Cr})$ & 80 & $100.0 \pm 0.0 \mathrm{a}$ & $5.46 \pm 1.53 \mathrm{a}$ & $6.54 \pm 0.29 \mathrm{a}$ & $12.0 \pm 1.53 \mathrm{ab}$ & $18.7 \pm 0.6 \mathrm{~b}$ \\
& 100 & $91.0 \pm 3.9 \mathrm{a}$ & $4.44 \pm 1.6 \mathrm{a}$ & $5.62 \pm 1.42 \mathrm{a}$ & $10.04 \pm 1.78 \mathrm{a}$ & $19.0 \pm 0.7 \mathrm{~b}$ \\
\hline
\end{tabular}

Figures followed by the same letters in the column are not significantly different at $\mathrm{P}<0.05$.

\pm Standard Error of the means.

\section{DISCUSSIONAND CONCLUSION}

Chromium produced a significant reduction in the growth of $P$. juliflora. The effect was mainly observed on root and shoot and to a lesser extent on seedling length. The inhibition of growth by chromium could be mainly due to the accumulation of chromium in the roots. Bishoni (1993) observed that hexavalent chromium applied as potassium di chromate did not affect the percentage germination of pea seed but the growth of radicles and plumule were significantly suppressed above $0.5 \mathrm{mM}$ concentration. Bishoni (1993) also noted that the deleterious effect of chromium was more pronounced on the growth of roots than on shoots. Concentration of metal in various plant parts was: roots >leaves >stem >pod walls > seeds. The present study showed the deleterious effect of chromium on roots due to its accumulation in the roots which was extremely limited in the shoots. Accumulation of chromium in roots was 100 fold higher than that by shoot regardless of the chromium supplied (Bishoni, 1993). Sharma and Aery (2000) found that low concentration of chromium was stimulatory to the plant growth while other workers contradicted it and observed that chromium is inhibitory and toxic to plant growth. Chromium toxicity manifested itself in plants by inhibiting the growth more or less, showing chlorosis with small brownish-red or purple leaves and necrotic lesions. High chromium concentration inhibits photosynthesis and greatly inhibits the root growth. It is therefore evident that chromium affects the plant growth mainly by damaging the root while its translocation into other parts of the plant is of minor importance. Warrage and Al-Humaid (1998) reported that $P$. juliflora plants possess allelochemicals that inhibit the germination and spread of other plant species. Similar observations were made by Noor et al. (1995) who reported that allelophatic effects of $P$. juliflora might be stronger and more effective. $P$. juliflora has been recognized as a serious weed because it spreads rapidly into valuable agricultural lands due to its easy propagation and ability to with stand adverse environmental conditions and heavy grazing (Leaky and Last, 1980). It also spreads rapidly due to its vigorous habit and dominating competitiveness with other vegetation.

Deleterious effect of chromium on plants suggests that chromium is very much toxic in nature and considered inhibitory to plant (Sharma and Aery, 2000). In contrast to chromium, aluminum did not affect the percentage of germination and dry biomass, all the seeds germinated within two days. The growth of plant as inhibited by chromium was not inhibited by aluminum. Aluminum enhanced the growth of root, shoot and seedling of $P$. juliflora. It did not affect the growth of plant up to concentration of $100 \mathrm{ppm}$. Thus aluminum can be considered a good stimulatory metal for plant growth. Some heavy metals at low doses are essential micronutrients for plants but in higher doses they may cause metabolic disorder and growth inhibitor for most of the plant species (Claire, 1991 and Ferandes and Henriques, 1991). Delhaize and Ryan (1995) and Marienfeld (2000) found that aluminum is not regarded as an essential nutrient but low concentration can sometime increase plant growth or induce other desirable effects. It may be concluded that aluminum is not as toxic as chromium. Prosopis manages to protect itself from aluminum by releasing its toxic compound and binds with other organic compounds internally for decreasing its toxicity. However, chromium inhibits the growth. Chromium is more toxic to plant growth than aluminum and their combined treatment showed the intermediate effect by ameliorating the impact of one another. 


\section{REFERENCES}

Bishoni, N. R., (1993). Effect of chromium on seed germination, seedling growth and yield of peas. Agric. Ecosyst. Environ., 47, 47-57.

Claire, L .C., Adriano, D. C., Sajwan, K. S., Abel, S. L., Thoma, D. P. and Driver, J. T., (1991). Effects of selected trace metals on germinating seeds of six plant species. Water, Air, Soil Pollut., 59, 231-24.

Delhaize, E. and Ryan, P. R., (1995). Aluminum toxicity and tolerance in plants. Plant Physiol., 107, 315-321.

Fernandes, J. C. and Henriques, F. S., (1991). Biochemical, physiological and structural effects of excess copper in plants. Bot. Rev., 57, 246-273.

Hailu, S., (2002). Some biological characteristics that foster the invasion of Prosopis juliflora (SW.) DC. at Middle Awash Rift Valley Area, Northeastern Ethiopia. M.Sc. Thesis, Addis Ababa University, Addis Ababa, Ethiopia.

Kassahun, Z., (1999). Prosopis (Prosopis juliflora) in Ethiopia (Fassil Reda, Tanner, D. G., Eds.). Arem., Ethiopian Weed Science Society, Addis Ababa, Ethiopia, 5, 96-102

Leaky, R. R. and Last, F. T., (1980). Biology and potential of Prosopis species in arid environments, with particular reference to P. cineraria. J. Arid Environ., 3, 9-24.

Leyval, C., Singh, V. B. R. and Joner, E. J., (1995). Occurrence and infectivity of arbuscular mycorrhizal fungi in some Norwegian soils influenced by heavy metals and soil properties. Water, Air and Soil Pollut., 84, 201-216.
Marienfeld, S., Schmohl, N., Klein, M., Schröder, W. H., Kuhn, A. J. and Horst, W. J., (2000). Localizations of aluminum in root tips of Zea mays and Vicia faba. J. Plant. Physiol., 156, 666-671.

Mohamed, A. E. F., (1997). Management of Prosopis juliflora for use in Sudan. Ph.D. Thesis, Helsinki, Finland.

Mullar, D. H., VanOort, F. and Balbane, M., (2000). Strategies of heavy metal uptake by three plant species growing near a metal smelter. Environ. Poll., 109, 231-238.

Noor, M., Salam, U. and Khan, M. A., (1995). Allelophatic effects of Prosopis juliflora Swartz. J. Arid Environ., 31, 83-90.

Sharma, A. and Aery, N .C., (2000). Studies on the phytoremidiation of zinc tailings. I. Growth performance of wheat, Vasundhara, 6, 45-50.

Vojtechova, M. and Leblova, S., (1991). Uptake of lead and cadmium by maize seedlings and the effects of heavy metals on the activity of phosphoenol pyruvate carboxilase isolated from maize. Biol. Plant. 33, 386-394.

Warrage, M. O. and Al-Humaid, A. I., (1998). Allelophatic effects of mesquite (Prosopis juliflora) foliage on seed germination and seedling growth of bermudagrass (Cynodon dactylon). J. Arid. Environ. 38, 237-243.

Welbaum, G. E., Bradford, K. J., Kyu-Ock, Y., Booth, D. T. and Oluoch, M. O., (1998). Biophysical, physiological and biochemical processes regulating seed germination. Soil Sci. Res., 8, 161-172.

\section{AUTHOR(S) BIOSKETCHES}

Jamal, Sh. N., B.Sc. (Hons.), M.Sc., is a lecturer in the Department of Botany, City College Karachi, and a Ph.D. research fellow in the Department of Botany, University of Karachi, Karachi, Pakistan. E-mail:shagi_83@hotmail.com

Iqbal, M. Z., B.Sc. (Hons.), M.Sc., Ph.D., is professor and chairman, Department of Botany, University of Karachi, Karachi, Pakistan. E-mail: mziqbalbotuokpk@yahoo.com

Athar, M., M.Sc., M.Phil., Ph.D., D.Sc., is a research scientist with the State of California, Department of Food and Agriculture, Sacramento, California, USA. E-mail: atariq@cdfa.ca.gov

\section{This article should be referenced as follows:}

Jamal, S. N., Zafar Iqbal, M. and Athar, M. (2006). Effect of aluminum and chromium on the growth and germination of mesquite (Prosopis juliflora swartz.) Dc. Int. J. Environ. Sci. Tech., 3 (2), 173-176. 